\title{
Problem-solving activity including trust and honesty: spotlighting 'ASD' students
}

\section{KEYWORDS}

creativity, ASD, OCD, perfectionism, deficits

\begin{abstract}
Janiec Jerzy, Problem-solving activity including trust and honesty: spotlighting 'ASD' students. Kultura Społeczeństwo - Edukacja nr 1(13) 2018, Poznań 2018, pp. 273-286, Adam Mickiewicz University Press. ISSN 2300-0422. DOI 10.14746/kse.2018.13.20.
\end{abstract}

How many times dear reader have you found yourself in a quite challenging situation (having an ambitious student, but with depression, social, emotional and interaction deficits, low self-esteem, OCD and everything connected with ASD) when the most crucial was timing (15 weeks and the same amount of subjects to pass by the given learner) and you have been looking for possible solutions without any further favorable outcomes wondering what should be another step of mine as educator in the upcoming end of the school year? This paper is some sort of answer on the given questions providing a far-reaching suggestion, after in-depth reflection and evaluation, for individual creative work in order to understand ASD students. Sometimes we need to give 'three steps back to move one step forward'. Three steps back is a diligent investigation that consists of four stages, namely stage of novitiate (refocus), stage of puzzles, and stage of fixing the puzzles and stage of creativity. What's more, we need to reflect on our thoughtfulness by analyzing acronym C.A.M.P.A.I.G.N.E.R. with specific personality traits. Possessing background knowledge about the problem and ourselves we can move forward by implementing creatively possible solutions to our circumstances remembering about being in every situation ourselves. 


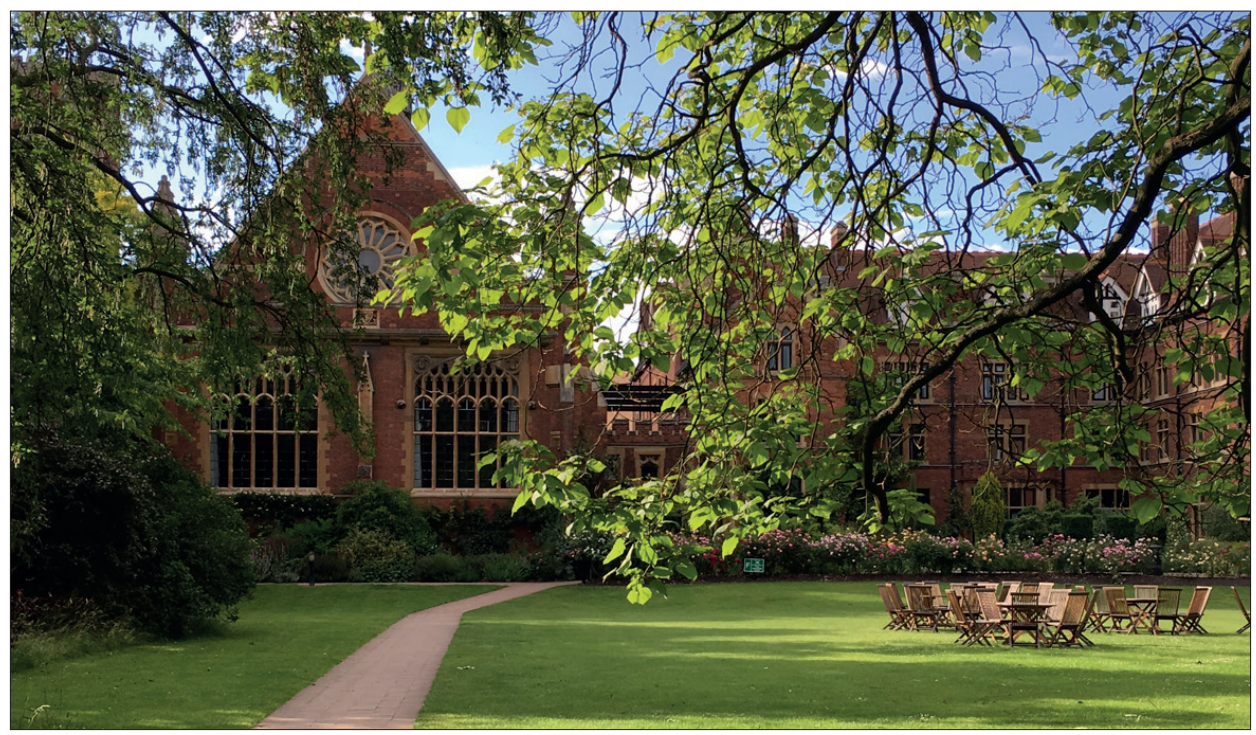

Fig. 1. Homerton Conference Centre, Cambridge, July 3, 2016

\section{Stimulus}

Having been fortuitous to attend a methodological course entitled "Creativity in the Classroom" with Chaz Pugliese (Arnold et al., 2015; Pugliese at al., 2010) in Homerton Conference Centre, Cambridge in July 4-15, 2016 1 , I caught sight of it even higher than just fruitful. On top of it, there are not many favorable circumstances to be in all respects a part of life changing experience throughout the whole savoir-fair in all one's born days. Being exhilarated to distribute inwardness likewise schemes from the school year 2015/2016 and more philosophical insights thanks to new colleagues-teachers encouragement ${ }^{2}$. What's more compelling, people have a tendency not to spend as much time on reflection as they perhaps should in order "to move one step forward after taking three steps back" (Chaz's words) also in the classroom. The emphasis on contemplating corresponds with

1 IB School No. 006654 International School of Bydgoszcz took part in two years Erasmus Plus program focusing mainly on linguistic and methodological teachers' up growth. The aforementioned course was organized by Bell Educational Services featuring worldwide-recognized ETL speakers, namely Jim Scrivener (Academic Director), Lyndsey Warwick (Chief Executive), Adrian Underhill, Anne Young, Jacquelin Douglas.

2 I would like to dedicate this paper to the whole 'Creativity in the Classroom' colleagues-teachers group, namely: Francesca, Juliana, Katarina, Magda, Marcia, Maya, Madeline, Natalia, Ute, Valle, Matt and Juan. Thank you for being one of the best teams ever. 
a question whether you know yourself in terms of strengths and weaknesses, but especially what are your personality traits that can make a difference in a classroom environment willing to be flexible as much as it is possible in order to teach children in the $21^{\text {st }}$ century (Levitin, 2015: 329-369).

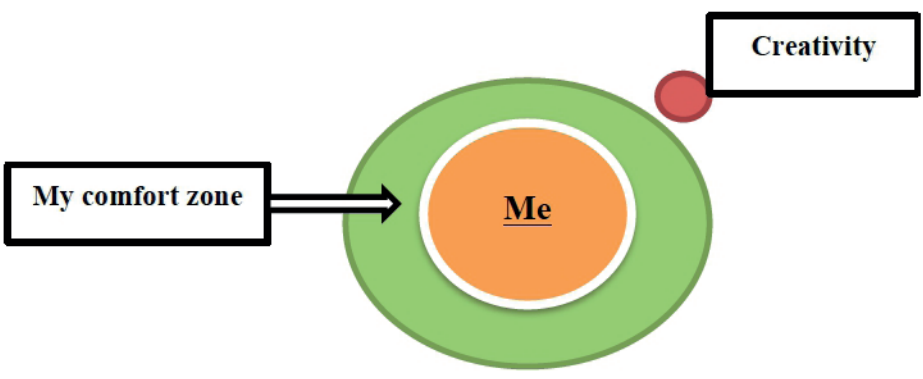

Schema 1 . Where does the creativity in teaching happen?

Author: Jerzy Janiec

Let just make these three steps back. Apart from the course content I was familiarized to NERIS Analytics Limited Company and its sixteen personalities test (NERIS 2016). Around $37,7 \mathrm{mln}$ people took it so far ${ }^{3}$, so a number of Polish inhabitants in their country. I had been quite skeptical and cynical beforehand, but after some time I just realized that result, hinging on a clear-cut algorithm, actually describes myself. There was an urgency to combine the latest finding with education and two far-reaching quotes:

Remember two things: that there is no such thing as right or wrong and that you need to trust the process [in the classroom, ed. JJ]. - Chaz Pugliese, (Gurr, 2013; Pugliese at al., 2010: 83-87)

More experienced colleagues tell me that I should play the role of a confident, knowledgeable teacher. As I walk into my classroom, I feel myself trying to become that teacher, but somehow I'm never comfortable with it and never quite sure how I should be in the classroom. (Scrivener, Thornbury, 2012: 36)

Have you ever reflected on a way of bonding people, making new friends and on a term 'team spirit'? Why trust and honesty are crucial factors for teachinglearning process? Why it is important to know students' moods, routines, hobbies, ways they learn and other attributes? What are the ways to put theory into practice? How to motivate your students? Why on the grounds that we will understand

\footnotetext{
${ }^{3}$ On a day July 23, 2016; hour: 18:25.
} 
Howard Gardner's $(1983 ; 1993)$ Multiple Intelligences Theory (MI theory) ${ }^{4}$ scholars are able to provide a meaningful learning environment not for themselves, but their students? Why any teacher should come as she/he is? (Scrivener, Thornbury, 2012: 36-39; taking also into account Adrian Underhill's suggestions from his workshop entitled "Developing Classroom Relationships through supportive Listening"). What are inclusion and differentiation? How they should work the best for my students? Why I am assuming that young learners are going to master information as I do? Why I am fixating merely on my strengths as a teacher not on my students'? (Pugliese et al., 2010: 84-85).

\section{Diligence}

Answering the given questions please imagine a situation, which you are going to be put in as educator and form teacher at once. One of your fourteen years old students is diagnosed with Obsessive-Compulsive Disorder $(\mathrm{OCD})^{5}$ of course including repetitive obsessions and compulsions in her behavior that occur at home, at school, during classes and breaks. After another set of interviews and sessions with psychologists, psychotherapists and other specialists she is spotted with Asperger Syndrome/ASD ${ }^{6}$ having above-average intelligence and a dint of being a perfectionist with social, communication and interaction deficits ${ }^{7}$. To make matters even worse she is taking medicines without any positive reactions, consultants are not certain how to help and you have only fifteen working weeks during second semester (5 days each) to make sure that your learner is going to pass this school year with fifteen subjects and its subject teachers on a check-in list to issue final marks. To add, she is getting handle on depression, panic attacks, and problems with vision, breath and low self-esteem these days.

${ }^{4}$ Forms of intelligences consist of: linguistic, musical, logical-mathematical, spatial, body-kinesthetic, intrapersonal and interpersonal.

5 Definition given by the National Institute of Mental Health (NIMH): 'Obsessive-Compulsive Disorder (OCD) is a common, chronic and long-lasting disorder in which a person has uncontrollable, reoccurring thoughts (obsessions) and behaviors (compulsions) that he or she feels the urge to repeat over and over.' Source: http://www.nimh.nih.gov/health/topics/obsessive-compulsive-disorder-ocd/index.shtml; 23.07.2016.

6 Nowadays categorization: Autism Spectrum Disorder (ASD).

7 For instance: 'getting upset by a slight change in a routine or being placed in a new or overly stimulating setting,' 'making little or inconsistent eye contact', 'failing to, or being slow to, respond to someone calling their name or other verbal attempts to gain attention', 'having difficulties with the back and forth of conversations'; from: NIMH, Autism Spectrum Disorder. Source: http://www.nimh. nih.gov/health/topics/autism-spectrum-disorders-asd/index.shtml; 23.07.2016. 
What would you do?

Beyond the bounds of any theory that is given on workshops, additional courses or in a form of guidance, here comes reality - metaphorically a skillful academic professor determined to scrutinize somebody's perception, maturity, awareness and dexterity in a real life scenario not in a written test or any other similarly relevant to school-like assignments. Notwithstanding this fact, the profile of criteria to assess your work is more likely to be the biggest concern. There is a chance of gauging individual from many perspectives by people having interest in the aforementioned matter, namely the teenage child, her family, friends, relatives, other parents and students, but in essence you will be able to hear only two convictions 'success' or 'misstep'. During my course on 'Creativity' our tutor addresses a fear of accepting failure as one of the main reasons why teachers do not want to move out of their comfort zone not opening a little bit wider doors for learning. One of the most pervasive sentences that you can read is, as follows:

Failure is simply a basic fact of life for the creative individual: what makes everything different is how the individual respond s. (Pugliese at al., 2010: 85)

In other words we need to find a smooth balance of everything overcoming obstacles and starting making our own research to refresh our knowing and understanding of the problem. Remembering that:

To think creatively is to learn to live one's life with d o ubt, indecision and uncertainty. Some individuals may not like this, because it leads to anxiety. Creative people are constantly confronted by darkness and far from being afraid, they quickly learn to a dapt and move swiftly. (Pugliese at al., 2010: 86)

The aim of being diligent in education is not only to work hard being assiduous, but also to recognize somebody's wants and needs likewise emotions, to create original and valuable solutions and implement them as soon as it is possible (Pugliese at al., 2010: 13-19; Scrivener, 1994: 82-98). Not having enough experience (a doubt) shall be exchanged with a self-taught process like the author's of this paper (sequencing process of adaptation). Finding yourself in a total stateof-art plight provokes you to speculate out of the box and moreover to discover unusual pathways that might be demonstrated in systematized stages behaving towards ASD students. My investigation consists of four levels:

a) Stage of novitiate or/and refocus may refer to any educator, whose area of expertise is dissimilar to psychology, biology, physics and chemistry, for instance a historian working as a form teacher. Perhaps it might be useful for 
experts in the aforegoing disciplines adjusting knowing and understanding on more scholarly ground. One of the main objectives here is to revise processes that happened in our body and mind as well as being introduced to neuroscience likewise neurodidactics building up some sort of a skeleton thanks to which we will be able to attach more detailed data after making generalizations (Berg et al., 2007; Bhikkhu Samahita, 2011; Feynman et al., 1965; Longstaff, 2012; Stapp 1993; Zemełka, 2015; Żychlińska, 2013).

b) We undergo stage of puzzle(s) by defining a problem, analogizing ${ }^{8}$ and discriminating ${ }^{9}$ this what we know and what should we know about any dilemma. In our case of study there is a necessity to pinpointed the successive puzzles of: perfectionism (Bonelli, 2015; Frank, 2015; Resources Result Relief, 2016; Smout, 2014); anxiety, communication and social deficits with their consequences (Falk et al., 2015; Fox, Francine, 1990; Hiber, 2011; Napora, 2011; Schwartz, 2016; Swallow at al., 2000; Waszczuk et al., 2015; Wojciechowska, 2011; Zabłocka 2011); OCD (Bryńska et al., 2011; Gorbis, 2016; Duncko, Veale, 2016; Pearcy et al., 2016; Smolińska, 2016), ASD (Attwood, 2006; Baron-Cohen, 2008; Berney, 2004; Garnett, 2013; Mazzone et al., 2012).

c) Stage of fixing the puzzles is a long term proceeding when we are trying to find connections between at least two open to doubt diagnoses, observing them from various perspectives, analysing their positives and negatives, advantages and disadvantages, risks and chances to grasp for example OCD phenomena - ASD - Autism - emotional experiences - quantum mechanics theory in neuroscience (changing a way of thinking and behaving of individual with ASD) - impact on peers and adults relationships, etc. (FischerTerworth, Probst, 2009; Losh, Capps, 2006; Kelly et al., 2008; Neziroglu, Henriksen, 2014; Paul, 2014; Russel, 2005; Ruzzano et. al., 2015; Samson et al., 2012; Schwartz et al., 2005; Sofronoff et al., 2005; 2011; Zandt et. al 2007).

d) Stage of creativity (on three types of creativities read: Pugliese et al., 2010: 11-12) corresponds with three above because finally we are able to aim for possible solutions starting with Jeffrey's Schwartz four steps self-treatment method to overcome OCD (Schwartz, 1996; 2002; 2011), mindfulness and cognitive therapies (Bays, 2015; Burdick, 2014; Gorbis, 2016; Gu et al., 2015; Hertenstein et al., 2015; MacCoon et al., 2013; McKay et al., 2015), way our

${ }^{8}$ Analogizing in teaching-learning process means to compare and contrast things in order to understand them.

${ }_{9}$ Discriminating in metaphorical sense is to make a shopping list of things 'what goes in' and 'what goes out'. 
learners acquire knowledge including MI theory (Caine, Nummela, 2001; Hüther 2016; Montessori, 1949), how to create a group of people with the same goal (Chybicka, 2006; Dweck, 2006), how to communicate with any student with obstacles being inspired by certain authors and their publications not necessarily connected with the subject matter (Dutta, 2015). All we need to do is to decide whether we are going to combine, explore or transform (Pugliese et al., 2010: 11-12) antecedent solutions in order to implement them to the new circumstances.

\section{Thoughtfulness}

On behalf of the previously acknowledged sixteen personalities test let me mention a campaigner who on one hand is a quite arduous person always sufficiently involved in malleable frame ${ }^{10}$ to accomplish a certain objective, for instance in education. According to NERIS's (2016) research there is only 7\% of population around the world that can be described by psychologists using campaigner's personality traits. On the other hand we may develop acronym ${ }^{11}$ - C.A.M.P.A.I.G.N.E.R. that consists of peculiar idiosyncrasies of any individual who would like to make changes in a particular field or assist her/his students with special educational needs in various frames. They are as follows:

- Curious = inquisitive: a teacher who is eager to learn something about people she/he is working with including ASD students using Socrates-like conversations as main armor.

- Anxious = thoughtful: a teacher who is showing consideration of others 'in the process' of learning in the classroom environment, but also in real life scenarios.

- Martial = courageous = gallant: a teacher who is able to face a difficulty without losing grip that is connected with state of mind and spirit. What's more she/he is not going to relinquish effortlessly after taking risk and coming across possible missteps. Brave personality will recover, acclimate and submit another quick fixes to adequate states of affairs in one's life.

- Passionate $=$ compassionate $=$ empathetic: a teacher who is acknowledged in any feasible crunch and is able to respond in accurate manner.

${ }_{10}$ Another word for a task, but this time more flexible with an opportunity to adjust self-referential data.

${ }^{11}$ Based on the third creative strategy introduced by Chaz Pugliese entitled 'S.C.A.M.P.E.R.' and creatively reused for educational purposes of this paper. 
- Acute = insightful: a teacher who is understanding, is having acumen (intuition), is able to see causes and consequences of the given dilemma and can predict unexpected.

- Indefatigable $=$ diligent $=$ independent: a teacher who is independently painstaking in order to aid those in need without looking behind.

- Genial: a teacher who is favorable for life, she/he is amicably and courteously good-natured.

- Newscaster = communicative: this is one of the most important personality traits because ASD students are choosing people to talk to (Barbeau et al., 2013; Hüther, 2014; 2015). You need to be very diplomatic in answering and asking questions without using unnecessary sarcasm or joke because learners might feel uncomfortable with.

- Energetic $=$ enthusiastic: this is one of the most difficult personality traits to keep because you need to be always ready for unexpected and reacted positively on every trigger in the air.

- Risk-taker $=$ doer, mover and shaker in order to create environment of understanding and appreciation what is going on with ASD students. Unfortunately, you will always take risks in that matter.

In a nutshell, remember to be yourself on every occasion. Please do not feel ashamed to involve intuition and feelings in a way you teach adolescents.

\section{Key}

Belatedly time has come to make a step forward. Firstly, bear in mind lock stock and barrel. By way of clarification as a result of comprehensive research you are capable of perceiving each and every even indiscriminate obstacle. By the same token by virtue of peculiar idiosyncrasies you have a proven capacity to go through somebody's mental state as well as you are able to deliberate with. Considering bringing together and infusing certain problems withal fishing for smart resolutions you may be ready to anticipate outcomes in advance. Being well appointed you might spend amazingly successive period on the genuine in existence battlefield.

Every milestone in educational positive energy driven get-up-and-go process ought to be reach thanks to commitment and equal embroilment of three elementary bodies in a shape of isosceles triangle, scilicet a student (on the top), a parent (on the right side) and a teacher / form teacher (on the left side). Please never undervalue hearing with a particular student and his parent in furtherance of any learner's wants and needs. A role of any listener is to hear along with using informa- 
tion rather than waiting for astute reply. Humanists are essential if it comes to leading dialogues. It might sound controversial, but a conversation can have some sort of remedial strength principally in exemplification where because of any rationale there was no chance of having this privilege at home. Acceptable communicator is going to open up slowly a given person stimulating a discussion to be aware of things that she can control, is able to excite and cannot influence obstacles (IB Team, 2016). We can react in a classroom observing what is going on with the pupil. Very useful are mindfulness strategies to control breath also Schwartz's four steps and exercises connected with behavioral therapies. Teacher-watcher should assess whether educate other classmates on a problematic case in the classroom. Everything depends on seriousness of the given situation. There is a huge possibility that the given student will be absent for a certain amount of time. We can use it wisely to prepare other children telling only this what they should know, not giving any details. Of course, I do not need to mention that regular contact with parents is fundamental.

After collecting all the data you can demonstrate results of your investigation to other teachers as well as management creating a supportive and caring team that has one aim - to watch over o u r student. Be prepared for sharing your idea how to work with ASD student in other classes. Each case is different, so one solution might be not suitable for every occasion, but making one misstep is not a tragedy in order to help adolescent. If your learner is more focused at school than at home do everything what you can to lower a number of homework that is given to her/ him. In order to make life at school for ASD student more predictable I would like to present, in a form of a table, my solution 'One subject per one week'. According to my student passing subjects weekly was less stressful and clearer what to do than in more traditional way. Knowing forms of assessment, working at school and being aware which criteria could have been checked made her feel prepared (even though being reserved she underlined one thing that she is no matter what always 'choppy').

Table 1. Example of solution named 'One subject per one week'

\begin{tabular}{|c|l|l|l|l|l|}
\hline Week & Subject(s) & Teachers & $\begin{array}{c}\text { Forms of Assessment } \\
\text { during Classes }\end{array}$ & IB Criteria & $\begin{array}{c}\text { Notes / Dates / Specifica- } \\
\text { tions / Descriptions }\end{array}$ \\
\hline 1 & English & $\ldots$ & $\begin{array}{l}\text { Movie analysis (written as- } \\
\text { signment) up to 350 words }\end{array}$ & A & $\ldots$ \\
\hline 2 & Spanish & $\ldots$ & $\begin{array}{l}\text { Power point presentation } \\
\text { Listening - paper }\end{array}$ & B C A & $\ldots$ \\
\hline 3 & Biology & $\ldots$ & $\begin{array}{l}\text { Written assignment up to } \\
220 \text { words }\end{array}$ & A & $\ldots$ \\
\hline
\end{tabular}




\begin{tabular}{|c|l|l|l|l|l|}
\hline 4 & Chemistry & $\ldots$ & $\begin{array}{l}\text { Atom's structure and peri- } \\
\text { odic table - presentation }\end{array}$ & A C D & $\ldots$ \\
\hline 5 & Physics & $\ldots$ & $\begin{array}{l}\text { Written assignment up to } \\
350 \text { words }\end{array}$ & A-D & $\ldots$ \\
\hline 6 & ICT & $\ldots$ & $\begin{array}{l}\text { Website or/and } \\
\text { Database }\end{array}$ & A-D & $\ldots$ \\
\hline 7 & $\begin{array}{l}\text { Physical } \\
\text { Education }\end{array}$ & $\ldots$ & 'Healthy Diet Menu' & A B D & $\ldots$ \\
\hline$\ldots$ & $\ldots$ & $\ldots$ & $\ldots$ & $\ldots$ & $\ldots$ \\
\hline
\end{tabular}

Source: author

Table 2. Suggested differentiable and editable set up of daily routines in each subject for ASD students

\begin{tabular}{|l|l|l|l|}
\hline \multicolumn{1}{|c|}{ Subjects } & \multicolumn{1}{|c|}{ Routines } & \multicolumn{1}{c|}{$\begin{array}{c}\text { Additional activities } \\
\text { in the classroom }\end{array}$} & \multicolumn{1}{c|}{ Notes } \\
\hline History & $\begin{array}{l}\text { Morning routines } \\
\ldots \\
\text { Afternoon routines } \\
\ldots \\
\text { 'Before you leave the } \\
\text { classroom' routines } \\
\ldots\end{array}$ & $\ldots$ & $\ldots$ \\
\hline$\ldots$ & $\ldots$ & $\ldots$ & $\ldots$ \\
\hline
\end{tabular}

Source: author

To conclude, the ASD student was the best in her class passing all of the fifteen subjects with the highest average (being more precise: twelve excellent grades and three very good marks) and having second best at school result fulfilling in outstanding manner all of the goals for school year 2015/2016. She was also a representative of the school in various competitions and she attended extra after school activities hooking up her wide range of hobbies that get a fix on music.

Thanks to "Creativity in the Classroom" course I was introduced to the three creative strategies. One of them was simplicity, which requires using people as resources. One thing sticks with me the most and I am very thankful for this lesson:

Simplicity is about adopting a frugal, minimalist, ecological, learner-centred and anti-exterior-clutter approach in the classroom. (Chaz Pugliese et al, 2010: 16) 


\section{References}

Arnold J., Dörnyei Z., Pugliese Ch. (2015). The Principled Communicative Approach: Seven Criteria for Success. London.

Attwood T. (2007). The Complete Guide to Asperger Syndrome. London.

Barbeau E. B., Soulières I., Dawson M., Zeffiro Th. A., Mottron L. (2013). The level and nature of autistic intelligence iii: inspection time. "Journal of Abnormal Psychology", Vol. 122.1, pp. 295-301.

Baron-Cohen S. (2008). Autism and Asperger Syndrome. Oxford.

Bays J.Ch. (2015). Mindfulness. Jak wytrenować dzikiego słonia i inne przygody w praktyce uważności. Trans. A. Wojtasik. Warszawa.

Berg J. M., Tymoczko J. L., Stryter H. (2007). Biochemia. Comp. Neil D. Clarke. Trans. Z. Szweykowska-Kuklińska, A. Jarmołowski. $5^{\text {th }}$ ed., Warszawa.

Berney T. (2004). Asperger syndrome from childhood into adulthood. "Advances in Psychiatric Treatment" Vol. 10, pp. 341-51.

BhikkhuSamahita (2011). Henry Stapp on the Conscious Choice and the Non-Local Quantum Entangled Effects. https://www.youtube.com/watch?v=HJN01s1gOqA, dostęp: 24.04.2016.

Bryńska A., Lipińska E., Matelska M. (2011). Objawy obsesyjno-kompulsyjne, tiki, stereotypy ruchowe czy dążność do zachowania stałości otoczenia? Występowanie powtarzalnych aktywności u pacjentów z całościowymi zaburzeniami rozwoju - opis przypadków. "Psychiatria Polska” Vol. 45.5, pp. $759-768$.

Burdick D.E. (2014). Mindfulness Skills for Kids \& Teens: A Workbook for Clinicans \& Clients with 154 Tools, Techniques, Activities \& Worksheets. Eau Claire, WI.

Caine G., Caine N.R. (2001). The Brain, Education, and the Competitive Edge. Lanham.

Chybicka A. (2006). Psychologia twórczości grupowej. Jak moderować zespoły twórcze i zadaniowe? Kraków.

Duncko R., Veale D. (2016). Changes in disgust and heart rate during exposure for obsessive compulsive disorder: a case series. "Journal of Behavior Therapy and Experimental Psychiatry", Vol. 51, pp. 92-99.

Dutta R. (2015). Lets talk: promoting dialogue and answerability in critical humanities education with permeable curriculum and an adda-based pedagogy. "Kultura -Społeczeństwo - Edukacja", Vol. 1.7, pp. 35-59.

Dweck C.S. (2006). Mindset: The New Psychology of Success. How we can learn to fulfill our Potential. New York.

Falk E.B., Brook O’Donnell M., Cascio Ch.N., Tinney F., Kang Y., Lieberman M.D., Taylor S.E., An L., Resnicow K., Strecher V.J. (2015). Self-affirmation alters the brain's response to health messages and subsequent behavior change. "Proceedings of the National Academy of Sciences Proc. Natl. Acad. Sci. USA”, Vol. 112.7, pp. 1977-1982.

Feynman R.P., Leighton R.B., Sands M.L. (1965). The Feynman Lectures on Physics. Quantum Mechanics. Reading, MA.

Fischer-Terworth Ch., Probst P. (2009). Obsessive-compulsive phenomena and symptoms in Asperger's disorder and high-functioning autism: an evaluative literature review. "Life Span and Disability", Vol. 12.1, pp. 5-27.

Fox L.C., Weaver F.L. (1990). Unlocking doors to self-esteem. Content-oriented activities for grades 7-12. Washington D.C. 
Gardner H. (1983). Frames of Mind. New York.

Gardner H. (1993). Multiple Intelligences: The Theory in Practice. New York.

Garnett M.S., Attwood T., Peterson C., Kelly A.B. (2013). Autism spectrum conditions among children and adolescents: a new profiling tool. "Australian Journal of Psychology", Vol. 64.4, pp. 206-213.

Gorbis E. (2005). Obsessive Compulsive Disorder. http://www.hope4ocd.com/ocd.php, dostęp: 12.04.2016.

Gorbis E., O’Neill J., Sterner J., Yip J., Molnar Ch. (2014). Mindfulness-based Behavioral Therapy (MBBT) for OCD. http://www.gatewayocd.com/wp-content/uploads/2014/06/Mindfulness_Article.pdf, dostęp: 12.04.2016.

Gu J., Strauss C., Bond R., Cavanagh K. (2015). How do mindfulness-based cognitive therapy and mindfulness-based stress reduction improve mental health and wellbeing? A systematic review and meta-analysis of mediation studies. "Clinical Psychology Review", Vol. 37, pp. 1-12.

Gurr T. (2013). In Praise of CREATIVITY (Pt 02 - from GUEST BLOGGER Chaz Pugliese). https:// allthingslearning.wordpress.com/tag/chaz-pugliese/, dostęp: 19.07.2016.

Hertenstein E., Rose N., Voderholzer U., Heidenreich Th., Nissen Ch., Thiel N., Herbst N., Katrin Külz A. (2012). Mindfulness-based Cognitive Therapy in Obsessive-compulsive Disorder - A Qualitative Study on Patients' Experiences. "Hertenstein Et Al. BMC Psychiatry", Vol. 12, pp. 1-10.

Hibner A. (2011). Sposoby reagowania młodzieży na presję społeczna jako funkcja różnic indywidualnych w oporowości psychologicznej oraz źródła presji. [In:] D. Borecka-Biernat (ed.). Zaburzenia w zachowaniu dzieci i młodzieży w kontekście trudnych sytuacji szkolnych i pozaszkolnych. "Impuls", pp. 76-99.

How to Overcome Perfectionism (and the Anxiety It Causes) - College Info Geek. (2015). Dir. Thomas Frank. Perf. Thomas Frank. https://www.youtube.com/watch?v=mrhvsQRKVUU, dostęp: 3.04.2016.

Hüther G. (2014). Wszystkie dzieci sa zdolne. Jak marnujemy wrodzone talenty? Trans. A. Lipiński. Słupsk.

Hüther G. (2015). Kim jesteśmy - a kim moglibyśmy być? Zachęta neurobiologiczna. Słupsk.

Hüther G. (2016) Mit Freude Lernen - Ein Leben Lang. Weshalb Wir Ein Neues Verständnis Vom Lernen Brauchen. Sieben Thesen Zu Einem Erweiterten Lernbegriff Und Eine Auswahl Von Beiträgen Zur Untermauerung. Göttingen.

IB Team. Mindfulness. Could It Change the Way You Teach? Ed. S.-M. Ovum. IB World. Magazine of the International Baccalaureate. Finding Calm in the Classroom. Is Mindfulness the Secret to Deeper Learning or Just a New Age Fad? Mar. 2016, pp. 11-19.

Kelly A.B., Garnett M.S., Attwood T., Peterson C. (2008). Autism spectrum symptomatology in children: the impact of family and peer relationships. "Journal of Abnormal Child Psychology", Vol. 36.7, pp. 1069-1081.

Levitin D.J. (2015). The Organised Mind: Thinking Straight in the Age of Information Overload. New York.

Longstaff A. (2012) Krótkie wykłady. Neurobiologia. Trans. A. Wróbel. Warszawa.

Losh M., Capps L. (2006). Understanding of emotional experience in autism: insights from the personal accounts of high-functioning children with autism. "Developmental Psychology", Vol. 42.5, pp. 809-818.

MacCoon D.G., Imel Z.E., Rosenkranz M.A., Sheftel J.G., Weng H.Y., Sullivan J.C., Bonus K.A., Stoney C.M., Salomons T.V., Davidson R.J., Lutz A. (2013). The Validation of an active control in- 
tervention for Mindfulness Based Stress Reduction (MBSR). "Behaviour Research and Therapy", Vol. 50.1, pp. 3-12.

Mazzone L., Ruta L., Reale L. (2012). Psychiatric comorbidities in Asperger Syndrome and high functioning autism: diagnostic challenges. "Annals of General Psychiatry", pp. 11-16.

McKay M., Wood J.C., Brantley J. (2015). Terapia dialektyczno-behawioralna (DBT). Praktyczne ćwiczenia rozwijające uważność, efektywność interpersonalna, regulację emocji i odporność na stres. Trans. J. Gołąb. Kraków.

Montessori M. (1949). The Absorbent Mind. Madras.

Napora E. (2011). Komunikacja rodziców z młodzieża - przeglą badań nad zagadnieniem. [In:] D. Borecka-Biernat (ed.). Zaburzenia $w$ zachowaniu dzieci i młodzieży w kontekście trudnych sytuacji szkolnych i pozaszkolnych. Kraków, pp. 174-197.

National Institute of Mental Health (NIMH). (2016). Obsessive-Compulsive Disorder (OCD). http:// www.nimh.nih.gov/health/topics/obsessive-compulsive-disorder-ocd/index.shtml, dostęp: 23.07.2016.

National Institute of Mental Health (NIMH). Autism Spectrum Disorder. http://www.nimh.nih.gov/ health/topics/autism-spectrum-disorders-asd/index.shtml. Dostęp: 23.07.2016.

NERIS Analytics Limited. (2011). It's so Incredible to Finally Be Understood. Free Personality Test, Type Descriptions, Relationship and Career Advice. https://www.16personalities.com/, dostęp: 24.07.2016.

Neziroglu F., Henriksen J. (2014) Differentiating Between Asperger's and Obsessive-Compulsive Disorder. https://iocdf.org/expert-opinions/expert-opinion-aspergers-and-ocd/, dostęp: 21.05.2016.

"Nobody Is Perfect": Psychotherapie Des Perfektionismus (Raphael M. Bonelli). (2015). Dir. Institut Für Religiosität in Psychiatrie \& Psychotherapie. Perf. R.M. Bonelli. https://www.youtube.com/ watch?v=9oKcSrq5WlU, dostęp: 3.04.2016.

Paul J.D. (2014). The vacuum of the mind: a self-report on the phenomenology of autistic, obsessivecompulsive, and depressive comorbidity. "Schizophrenia Bulletin", Vol. 41.6, pp. 1207-1210.

Pearcy C.P., Anderson R.A., Egan S.J., Rees C.S. (2016). A Systematic review and meta-analysis of self-help therapeutic interventions for obsessive-compulsive disorder: is therapeutic contact key to overall improvement? "Journal of Behavior Therapy and Experimental Psychiatry", Vol. 51, pp. 74-83.

Pugliese Ch., Burghall M., Clandfield L. (2010). Being Creative: The Challenge of Change in the Classroom. Peaslake.

Resources Result Relief (2014), AnxietyBC. Helping Your Child Overcome Perfectionism. http://www. anxietybc.com/sites/default/files/OvercomingPerfectionism.pdf, dostęp: 3.04.2016.

Russell A.J., Mataix-Cols D., Anson M., Murphy D.G.M. (2005). Obsessions and compulsions in Asperger Syndrome and high-functioning autism. "The British Journal of Psychiatry", Vol. 186, pp. 525-528.

Ruzzano L., Borsboom D., Geurts H.M. (2014). Repetitive Behaviors in Autism and Obsessive-Compulsive Disorder: New Perspectives from a Network Analysis. "Journal of Autism and Developmental Disorder", Vol. 45.1, pp. 192-202.

Samson A.C., Huber O., Gross J.J. (2012). Emotion regulation in Asperger's Syndrome and high-functioning autism. "Emotion", Vol. 12.4, pp. 659-665.

Schwartz J.M., Begley Sh. (2002). The Mind and the Brain: Neuroplasticity and the Power of Mental Force. New York. 
Schwartz J.M., Beyette B. (1996). Brain Lock: Free Yourselffrom Obsessive-compulsive Behavior: A Four-step Self-treatment Method to Change Your Brain Chemistry. New York.

Schwartz J.M., Gladding R. (2011). You Are Not Your Brain: The 4-step Solution for Changing Bad Habits, Ending Unhealthy Thinking, and Taking Control of Your Life. New York.

Schwartz J.M., Stapp H.P., Beauregard M. (2005). Quantum physics in neuroscience and psychology: a neurophysical model of mind-brain interaction. "Philosophical Transactions of the Royal Society B: Biological Sciences", Vol. 360.1458, pp. 1309-1327.

Schwartz K. (2016). 20 Tips to Help De-escalate Interactions With Anxious or Defiant Students. http:// ww2.kqed.org/mindshift/2016/04/21/20-tips-to-help-de-escalate-interactions-with-anxiousor-defiant-students/, dostęp: 2.05.2016.

Scrivener J. (1994.) Learning Teaching: A Guidebook for English Language Teachers. Oxford.

Scrivener J., Thornbury S. (2012). Classroom Management Techniques. Cambridge.

Smolińska J. (2016). Nerwica natręctw: objawy i leczenie. http://www.poradnikzdrowie.pl/zdrowie/ uklad-nerwowy/nerwica-natrectw-objawy-i-leczenie_38382.html, dostęp: 4.04.2016.

Smout K. (2014). 5 Ways to Help Perfectionistic Students. "Developing Minds". http://developingminds.net.au/5-ways-to-help-perfectionistic/, dostęp: 2.04.2016.

Sofronoff K., Attwood T., Hinton Sh. (2005). A randomised controlled trial of a CBT intervention for anxiety in children with Asperger Syndrome. "Journal of Child Psychology and Psychiatry", Vol. 46.11, pp. 1152-1160.

Sofronoff K., Eloff J., Sheffield J., Attwood T. (2011). Increasing the understanding and demonstration of appropriate affection in children with Asperger Syndrome: A pilot trial. "Autism Research and Treatment", Vol. 2011, pp. 1-8. https://www.hindawi.com/journals/aurt/2011/214317/

Stapp H.P. (1993) Mind, Matter, and Quantum Mechanics. Berlin.

Swallow W.K., Halse L. Anderson. (2000) The Shy Child: Helping Children Triumph over Shyness. New York.

Waszczuk M.A., Zavos H.M.S., Antonova E., Haworth C.M., Plomin R., Eley Th.C. (2015). A multivariate twin study of trait mindfulness, depressive symptoms, and anxiety sensitivity. "Depression and Anxiety", Vol. 32.4, pp. 254-261.

Wojciechowska L. (2011). Dobrostan psychiczny adolescenta $w$ obliczu realizacji rozwojowych zadań społecznych. [In:] Borecka-Biernat D. (ed.). Zaburzenia w zachowaniu dzieci i młodzieży w kontekście trudnych sytuacji szkolnych i pozaszkolnych. Kraków, pp. 12-49.

Zabłocka M. (2011). Zaburzenia w zachowaniu dzieci i młodzieży w kontekście trudnych sytuacji szkolnych i pozaszkolnych. [In:] D. Borecka-Biernat (ed.). Zaburzenia w zachowaniu dzieci i młodzieży w kontekście trudnych sytuacji szkolnych i pozaszkolnych. Kraków, pp. 274-306.

Zandt F., Prior M., Kyrios M. (2007). Repetitive behaviour in children with high functioning autism and obsessive compulsive disorder. "Journal of Autism and Developmental Disorders", Vol. 37, pp. 251-259.

Zemełka A. (2015). Neuronauka od podstaw. Vademecum dla terapeutów, doradców i trenerów. Warszawa.

Żychlińska M. (2013). Neurodydaktyka. Nauczanie i uczenie się przyjazne mózgowi. Toruń. 